\title{
Chondromyxoid Fibroma of Lumbar Vertebrae: Case Report and Literature Review
}

\author{
ismail KAYA, MD*
}

Department of Neurosurgery, Ministry of Health, Şırnak State Hospital, Republic of Turkey

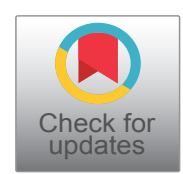

*Corresponding author: İsmail Kaya, MD, Department of Neurosurgery, Şırnak State Hospital, Ministry of Health, Şirnak/ Turkey, Tel: 054-692-573-40

\begin{abstract}
Objective: Chondromyxoid fibroma is a benign tumor of long bone metaphysis. In this article, we reported L4 laminar attachment of chondromyxoid fibroma case and made extensive literature revive.

Methods: A 56-year-old Caucasian female unable to walk without pain at her right leg diagnosed with chondromyxoid fibroma at right 14 lamina.

Result: Complete excision of the lesion via routine lumbar disc surgery with 6 months follow up without pain. Her Hypoesthesia cured also muscle weakness totally recovered.

Conclusion: Chondromyxoid fibroma is rare bone tumor even rarer spinal involvement. Because of total removal can cure disease and partial removal has chance of malignant transformation we must consider chondromyxoid fibroma in our differential diagnosis.
\end{abstract}

\section{Keywords}

Chondromyxoid fibroma, Lumbar vertebrae, Literature review

\section{Abbreviations}

Cmf: Chondromyxoid fibroma; L: Lumbar; MRI: Magnetic resonance imaging

\section{Highlights}

- Chondromyxoid fibroma must be considered for differential diagnosis of low back pain.

- Extensive surgery provides good results with a very low rate of recurrence.

- More work must be put to understand nature of Chondromyxoid fibromas.

\section{Introduction}

Chondromyxoid fibroma (cmf) is a benign tumor of long bone metaphysis. Jaffe and Lichtenstein first described in 1948 [1]. Although, chondromyxoid fibroma is a relatively rare tumor spinal attachment is even rarer. Chondromyxoid fibroma more frequently found cervical and thoracic segment. To our knowledge 11 case of lumbar chondromyxoid fibroma cases has described until this case (Table 1) [2-10].

In this article, we reported lumbar (L) 4 laminar attachment of chondromyxoid fibroma case and made extensive literature review.

\section{Material and Methods}

A 56-years-old Caucasian female was coming to our clinic with unable to walk without pain at her right leg. Patient didn't describe neurologic claudication. Her complaints have been worsened for 6 months. Patient has no incontinence.

Her physical exam showed right lasegue positivity at 30-degree, right extensor hallucis longus muscle weakness as much as $2 / 5$. Also, right $L 5$ dermatomal hypoesthesia.

Plain X-ray showed no significant indication of chondromyxoid fibroma because of adherent structures and superposition of multiple layers (Figure 1 and Figure 2).

Magnetic resonance myelogram showed cerebrospinal fluid flow obstruction on L4-5 disc space (Figure 3). T1-weighted images showed low signal intensity adherent to right L4 lamina and foramina stenosis (Figure 4). T2-weighted images showed high signal lesion with low signal intensity rim, which is very similar to neighbor bony structure (Figure 5 and Figure 6).

We suspected extrude disc herniation. An informed

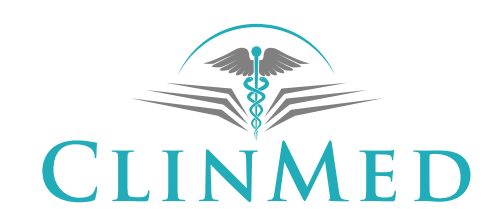

INTERNATIONAL LIBRARY
Citation: KAYA I (2020) Chondromyxoid Fibroma of Lumbar Vertebrae: Case Report and Literature Review. Neurosurg Cases Rev 3:043. doi.org/10.23937/2643-4474/1710043

Accepted: September 29, 2020; Published: October 01, 2020

Copyright: (C) 2020 KAYA I. This is an open-access article distributed under the terms of the Creative Commons Attribution License, which permits unrestricted use, distribution, and reproduction in any medium, provided the original author and source are credited. 


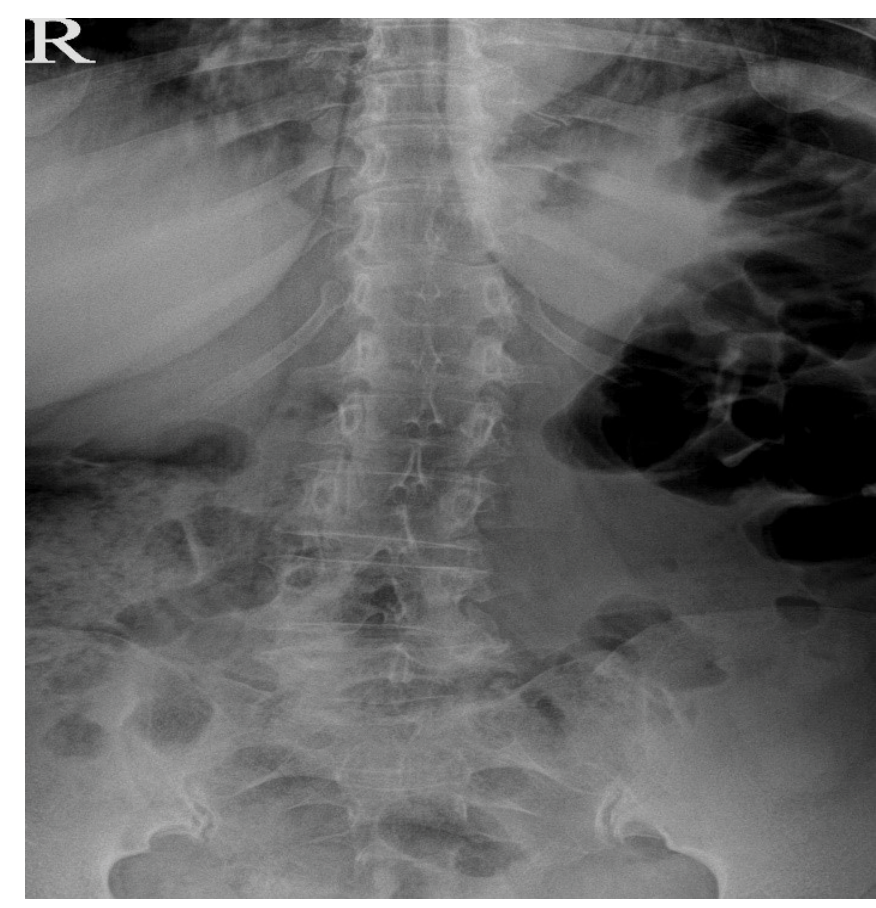

1

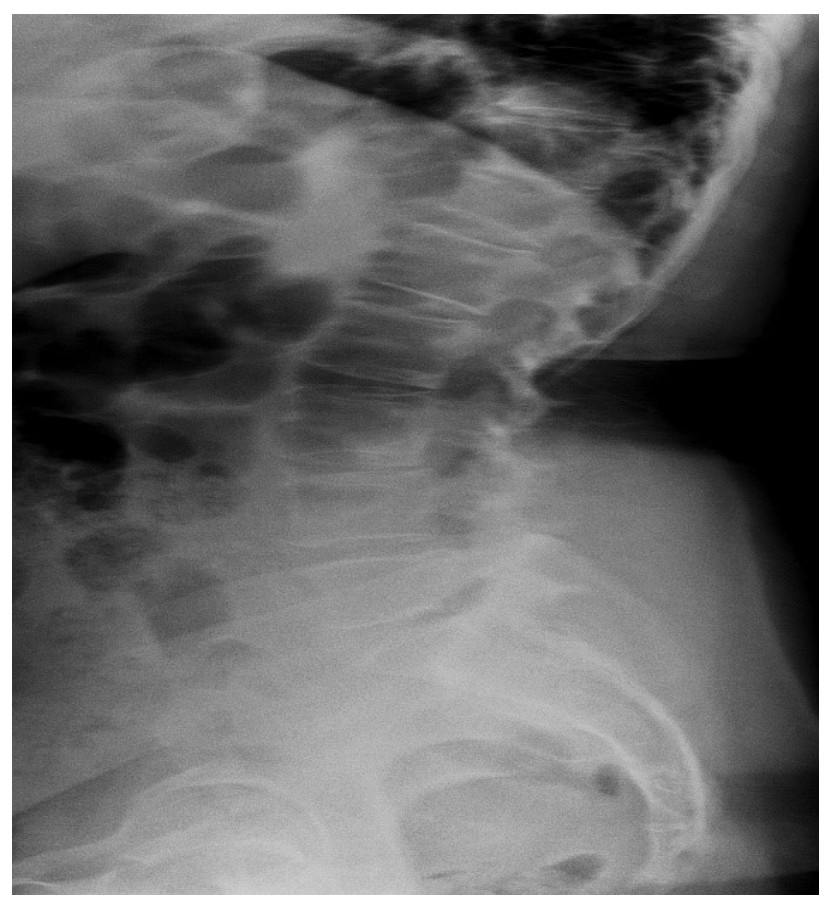

2

Figure 1 and Figure 2: Plain X-ray (anteroposterior and lateral orientations).

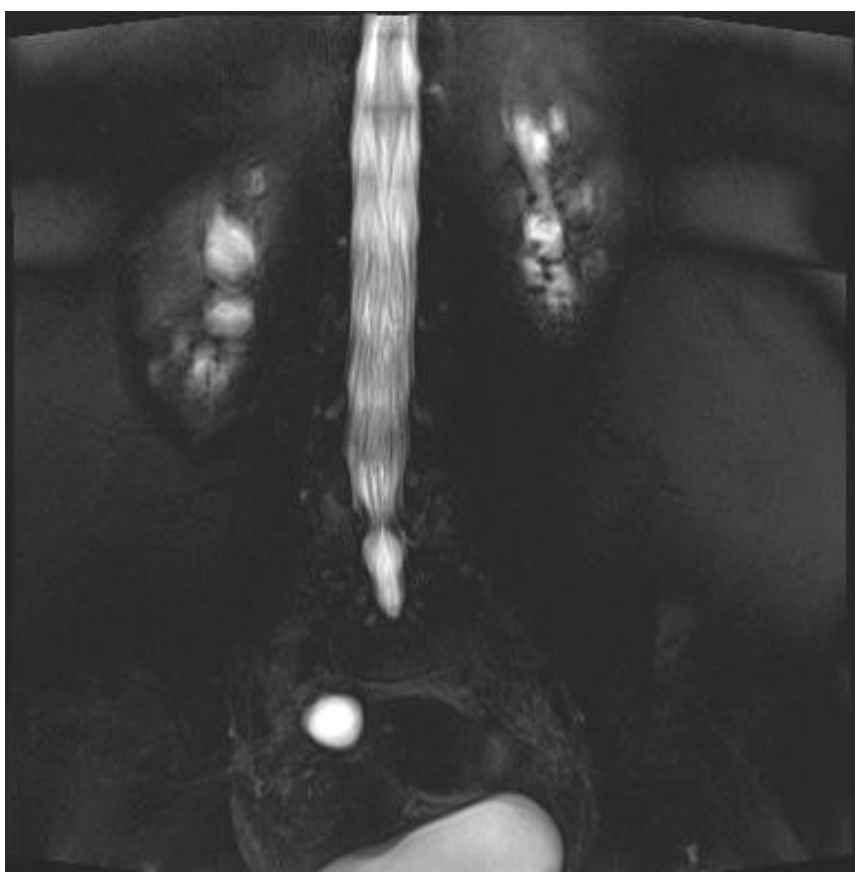

3

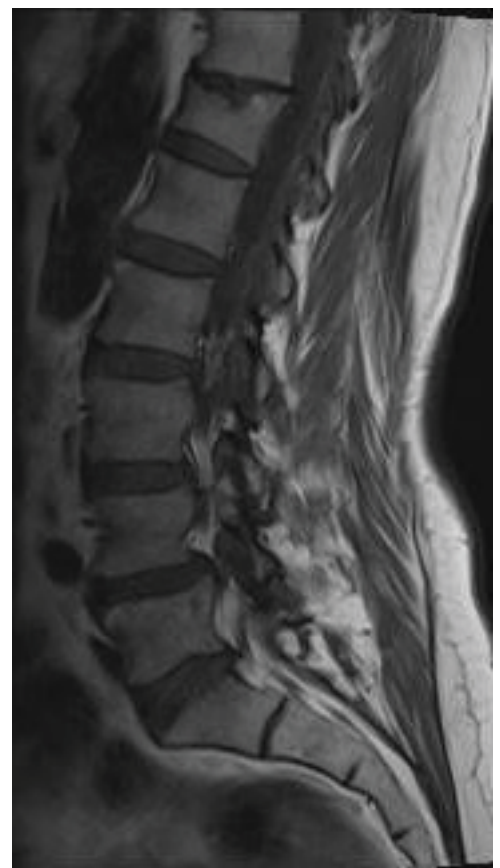

4

Figure 3 and Figure 4: Magnetic resonance myelogram and T1-weighted sagittal magnetic resonance images.

consent was obtained from patient in accordance the preoperative Turkish Neurosurgical Society consent form list and it was clearly stated that the data could be used in pursuant of ethical rules. According to planned surgery patient went under general anesthesia. Patient carefully placed tilting operating table and positioned as genupectorally. We used scopy to identify surgical area. After we made adequate cleaning and closure identified skin and subcutaneous tissue passed via 2 centimeters of midline skin incision. Right paravertebral muscles dissected using periosteal elevator. Right lamina of $L 4$ vertebrae totally removed and it was very soft purple colored mass that pressing L5 root. Routinely curated bony margins. We suspected malignancy and sampled it. There was no extrude disc material and posterior longitudinal ligament was intact. After foraminotomy per- 


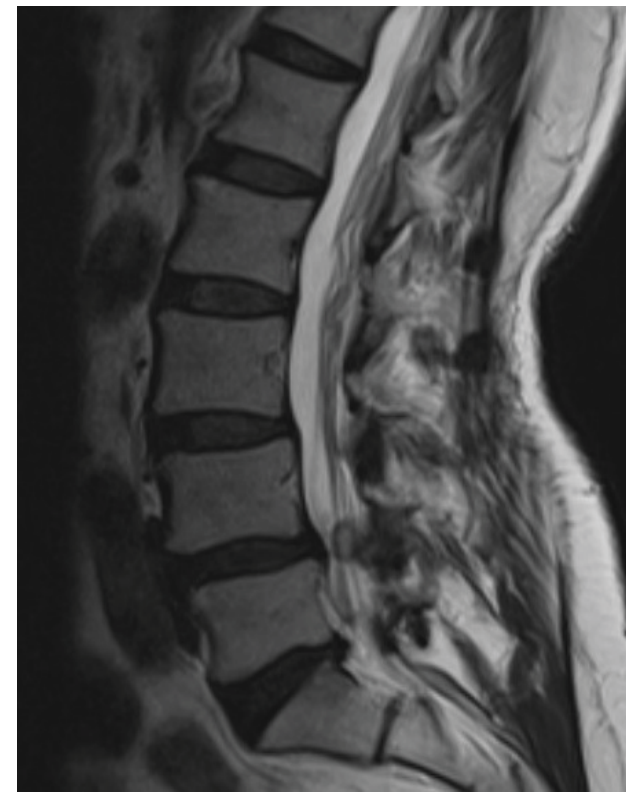

5

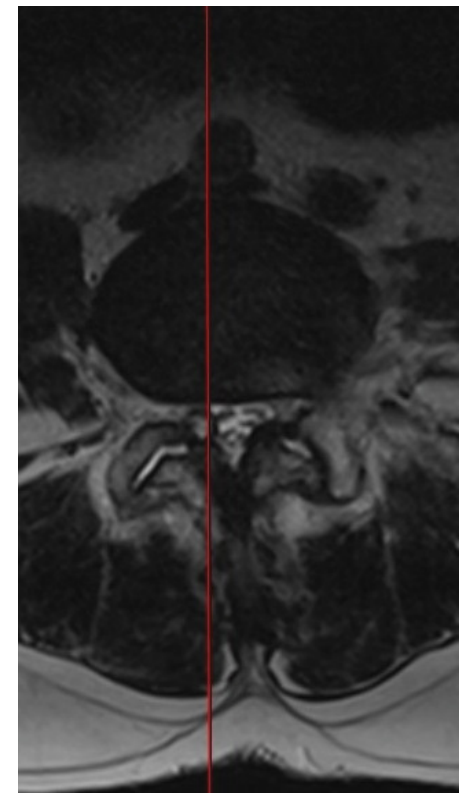

6

Figure 5 and Figure 6: T2-weighted sagittal and axial magnetic resonance images.

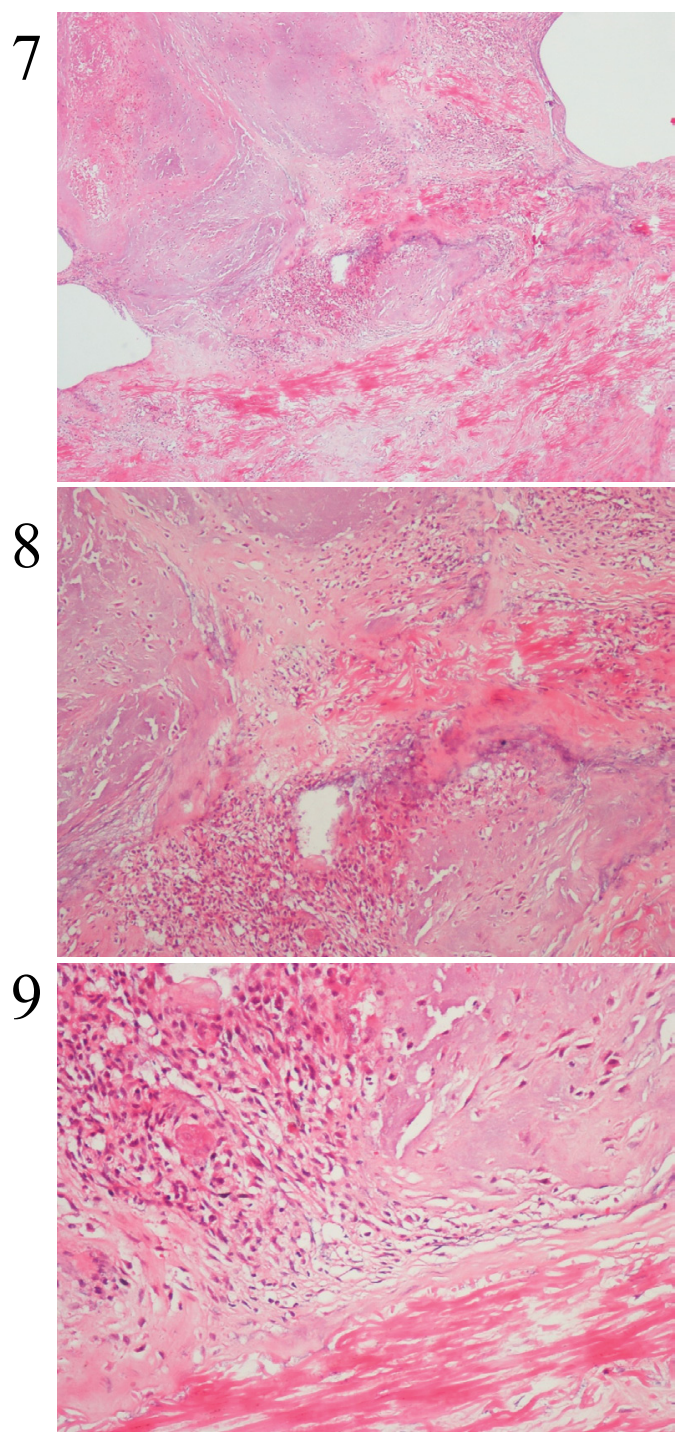

Figure 7, Figure 8 and Figure 9: Chondroid areas with giant cell and fibroblast like cells from our case (H\&E X4) (x40, x100, x200 magnifications). formed hemostasis provided. Layers closed according to anatomical orientation. $2 \mathrm{gr}$ cephazolin was used for prophylactic purposes (Figure 7, Figure 8 and Figure 9).

\section{Results}

Histopathological diagnosis confirmed as chondromyxoid fibroma. Patient followed for 6 months without pain. Her hypoesthesia cured also muscle weakness totally recovered.

\section{Discussion}

Chondromyxoid fibroma is a rare slow-growing bone tumor first described by Jaffe and Lichtenstein in 1943 $[1,7,11-13]$. Benson and Bass were report first spinal case [14]. Chondromyxoid fibroma is responsible for fewer than $1 \%$ of primary bone tumors. More than 500 cases of $\mathrm{cmf}$ have ever been described in the world literature. Most of chondromyxoid fibroma (around 75\%) occurs metaphysis of long tubular bones. Half of chondromyxoid fibroma is localized to femur and tibia. Chondromyxoid fibroma may extend into diaphysis or even rarely epiphysis. It can be purely diaphyseal, but it is never a pure epiphyseal lesion. Mainly second and third decades of life young patients effected [15-17]. Chondromyxoid fibroma exceptionally located in the spinal area. In this scarcity mostly found in thoracic spine. According to up to date literature lumbar vertebral area is least affected. At the day this paper published there were 11 cases of lumbar chondromyxoid fibroma reported (Table 1). Even if some reports have some slight differences there is no gender predominance (Schajowicz and $\mathrm{H}$ Gallardo). Etiology of the development of chondromyxoid fibroma is unknown [18].

Conventional radiography provides the most cost-ef- 
Table 1: Literature review of chondromyxoid fibroma of the lumbar spine.

\begin{tabular}{|c|c|c|c|c|c|c|}
\hline References & $\begin{array}{l}\text { Age } \\
\text { (years)/Sex }\end{array}$ & Location & Column & Symptoms & Treatment & $\begin{array}{l}\text { Follow-up } \\
\text { (Months) }\end{array}$ \\
\hline Gudscha [2] & $23 / F$ & L3 & Anterior (Body) & $\begin{array}{l}\text { Back pain; Leg } \\
\text { Weakness }\end{array}$ & Excision & $\begin{array}{l}36, \text { No } \\
\text { Recurrence }\end{array}$ \\
\hline Ramani, et al. [3] & $44 / \mathrm{M}$ & L1 & Pedicle & $\begin{array}{l}\text { Cauda Equina } \\
\text { Syndrome }\end{array}$ & Excision & $\begin{array}{l}\text { 2, No } \\
\text { Recurrence }\end{array}$ \\
\hline Tsuji, et al. [4] & 9/M & L4 & $\begin{array}{l}\text { Posterior (Lamina, } \\
\text { Pedicle) }\end{array}$ & Back Pain & $\begin{array}{l}\text { Excision + Bone } \\
\text { graft }\end{array}$ & $\begin{array}{l}\text { 44, No } \\
\text { Recurrence }\end{array}$ \\
\hline Mayer [5] & $23 / \mathrm{M}$ & L2 & $\begin{array}{l}\text { Posterior (Spinous } \\
\text { Processa) }\end{array}$ & Asymptomatic & Biopsy & - \\
\hline Cabral, et al. [6] & $19 / F$ & L1-L2 & $\begin{array}{l}\text { Posterior (Pedicle, } \\
\text { Transverse Process) }\end{array}$ & Leg Pain & Extensive Excision & $\begin{array}{l}60, \\
\text { Recurrence }\end{array}$ \\
\hline Wu, et al. [7] & - & $\begin{array}{l}\text { Three Cases, } \\
\text { Lumbar }\end{array}$ & - & - & $\begin{array}{l}\text { Curettage or } \\
\text { Excision }\end{array}$ & - \\
\hline Saldua, et al. [8] & $8 / \mathrm{M}$ & L3 & Posterior (Pedicle) & Back Pain & $\begin{array}{l}\text { Biopsy; } \\
\text { Excision + Fusion }\end{array}$ & $\begin{array}{l}\text { 13, No } \\
\text { Recurrence }\end{array}$ \\
\hline $\begin{array}{l}\text { Raquel Gutiérrez- } \\
\text { González, et. al. [9] }\end{array}$ & $21 / \mathrm{M}$ & L5 & $\begin{array}{l}\text { Posterior (Inferior } \\
\text { Articular Process) }\end{array}$ & Back Pain & Excision & $\begin{array}{l}\text { 12, No } \\
\text { Recurrence }\end{array}$ \\
\hline $\begin{array}{l}\text { Ming-Xiang Zou, et } \\
\text { al. [10] }\end{array}$ & $60 / F$ & L1 & $\begin{array}{l}\text { Anterior and Middle } \\
\text { (Body) }\end{array}$ & $\begin{array}{l}\text { Cauda Equina } \\
\text { Syndrome }\end{array}$ & Excision & - \\
\hline Present Case & $56 / F$ & L4 & Posteriyor (lamina) & Radiculopathy & Excision & $\begin{array}{l}6, \text { No } \\
\text { recurrence }\end{array}$ \\
\hline
\end{tabular}

fective diagnostic information of any imaging modality. However complex structure and adherent neighbors of spine limits its usefulness. Unless contraindicated Magnetic resonance imaging (MRI) recommended over computed tomography before surgery. Conventional radiographs show a well-marginated, expansile, lucent, eccentric, medullary lesion [19]. Lesions margins usually appear sclerotic and rarely contain visible calcification [15]. Computed tomography scan gives more detailed information about chondromyxoid fibroma. Primarily used for MRI contraindicated patients and to identify cortical integrity. Contrast enhancement is variable depends on lesion fibroid components and vascularity. Magnetic resonance imaging the best all-around imaging modality that shows extends of the lesion. Magnetic resonance imaging shows broad array of differences about nature of lesion. In general, low signal intensity on T1-weighted images and heterogenic high signal intensity on T2-weighted images. Also, sclerotic rim and calcification may result hypo intense rim at $\mathrm{T2}$-weighted images. Small lesions as well as some of larger lesions may demonstrate homogenous high signal intensity. Contrast enhancement images have heterogeneous signal intensity [20].

Radiologically chondrosarcoma, osteoblastoma, giant cell tumor of bone metastasis, Multiple myeloma, hemangioma, and aneurismal bone cysts must be considered in mind [20].

Macroscopically, chondromyxoid fibroma ranges white to grayish white and the maintains the lobular growth pattern. The rim may show bone formation. Cystic and hemorrhagic areas may mimic those seen aneurysmal bone cyst.
Microscopically, growth is nodular with a high degree of cellularity in the periphery of the nodules. Production of either chondroid or fibrocartilaginous matrix may be observed. The cellular foci consist of either spindle-shaped, fibroblast like cells or more myxoid, stellate cells. Mitoses are infrequent. Calcification is found microscopically in approximately one fourth of the patients. These patients usually old or lesions are near the bone surface. The extracellular matrix is abundant, myxoid connective tissue and chondroid material. Giant cells are frequent. Occasionally, the degree of cellularity and nuclear atypia approaches that characteristic of malignancy. However, confusion with chondrosarcoma in usually based on the appearance of the peripheral. Microscopically aneurysmal bone cysts, simple bone cysts, non-ossifying fibroma, giant cell bone tumor and chondrosarcoma must consider in mind for differential diagnosis. Typical view can easily distinguish. Since chondrosarkoid transformation at risk, special attention must be paid for atypia [19]. The stellate cells show features of both chondroblastic and stellate fibroblastic differentiation on electron microscopy [18]. Histologic features don't predict outcome $[13,21,22]$. Pericentrometric inversion; inv (1) (p25q13) is suggested diagnostic marker fort his tumor [15]. According to Sawyer, et al. 6q13-21 chromosomal abbreviation is found responsive local aggressive behavior.

Since, spinal involvement of this rare tumor is even rarer treatment modalities and long term follow up is dictated by surgeon's experiences. Hence, there is no established protocol. En-block resection is the best treatment of choice $[11,13,18]$. If not possible radical curettage and corticocancellous bone grafting must be 
done $[13,18,21]$. Studies showed en-block resection have lowest recurrence rates on the other hand curettage alone have highest (as much as $80 \%$ ) recurrence rates $[7,12,13,18]$. So, if curettage is feasible surgical option bone grafting must be added $[13,22]$. Also, according to Zilmer and Dorfman curettage alone leaves tumor lobules behind [22]. There are other surgical techniques such as intralesional excision, or marginal resection $[4,21,22]$. All other techniques have higher recurrence rates.

In case of recurrence radical treatment advocated due to tumor nature and possibility of malignant transformation. Since, radical excision is treatment principle surgical procedure depends on attached area, patient demographic and tumor invasion.

In our case we made en-block resection and curettage. Since surgery 6 month follow up shows no recurrence.

\section{Conclusion}

Chondromyxoid fibroma is rare bone tumor even rarer spinal involvement. Because of, malignant transformation possibility radical removal is treatment of choice and chondromyxoid fibroma always consider in mind. Surgical treatment depends on attached area, patient demographic, and tumor invasion. Since, tumor has a recurrence reports even if complete removal close follow up must be warranted. More work must be put to understand nature of this rare subject.

\section{Acknowledgements}

Special thanks for my bellowed wife Damla KAYA unquestionable support. Also, I am grateful to Cumhuriyet University Hospital Department of Pathology for providing slides.

\section{Conflict of Interest}

Author doesn't have any potential conflict of interest. This research did not receive any specific grant from funding agencies in the public, commercial, or not-forprofit sectors.

\section{References}

1. Jaffe $H L$, Lichtenstein $L$ (1948) Chondromyxoid fibroma of bone. A distinctive bone tumor likely to be mistaken especially for chondrosarcoma. Arch Pathol 45: 541-551.

2. Gudscha A (1968) A case of chondromyxoid fibroma of the spine. Ortop Traum Protez 29: 50-52.

3. Ramani PS (1974) Chondromyxoid fibroma: A rare cause of spinal cord compression. J Neurosurg 40: 107-109.
4. Tsuji H, Otsuka Y, Tamaki T, Takada N (1975) Chondromyxoid fibroma of vertebra. Report of a case. J Jpn Orthop Assoc 49: 305-312.

5. Mayer BS (1978) Chondromyxoid fibroma of lumbar spine. J Can Assoc Radiol 29: 271-272.

6. Cabral CEL, Romano S, Guedes P, Nascimento A, Nogueira J, et al. (1997) Chondromyxoid fibroma of the lumbar spine. Skeletal Radiology 26: 488-492.

7. Wu CT, Inwards C, O'laughlin S, Rock M, Beabout J, et al. (1998) Chondromyxoid fibroma of bone: A clinicopathologic review of 278 cases. Human Pathol 29: 438-446.

8. Saldua NS, Riccio AI, Cassidy JA (2008) Chondromyxoid fibroma of the lumbar spine in a pediatric patient. Orthopedics 31: 610 .

9. Gutierrez-Gonzalez R, De Reina L, Saab A, Jimenez-Heffernan J, Garcia-Uria J (2011) Chondromyxoid fibroma of the lumbar spine: Case report and literature review. Eur Spine J 21: 458-462.

10. Zou MX, LV GH, Li J, Wang XB (2016) Acute cauda equina syndrome secondary to chondromyxoid fibroma of the lumbar spine. The Spine Journal 16: e587-e588.

11. Feldman F, Hecht HL, Johnston AD (1970) Chondromyxoid fibroma of bone. Radiology 94: 249-260.

12. Rahimi A, Beabout JW, Ivins JC, Dahlin DC (1972) Chondromyxoid fibroma: A clinicopathologic study of 76 cases. Cancer 30: 726-736.

13. Unni KK (1996) Dahlin's bone tumors: General Aspects and Data on 11,087 cases. American Journal of Clinical Pathology.

14. Benson WR, Bass S (1995) Chondromyxoid fibroma first report of occurrence of this tumor in the vertebral column. Am J Clin Pathol 25: 1290-1292.

15. Granter SR, Renshaw AA, Kozakewich HP, Fletcher JA (1998) The pericentromeric inversion, inv(6)(p25q13), is a novel diagnostic marker in chondromyxoid fibroma. Mod Pathol 11: 1071-1074.

16. Ralph LL (1962) Chondromyxoid fibroma of bone. J Bone and Joint Surg 44B: 7-24.

17. Schutt PG, Frost HM (1971) Chondromyxoid fibroma. Clin Orthop Relat Res 78: 323-329.

18. Schajowicz F, Gallardo H (1971) Chondromyxoid fibroma (fibromyxoid chondroma) of bone: A clinico-pathological study of thirty-two cases. J Bone Joint Surg Br 53: 198-216.

19. Vigorita VJ (2016) Orthopedic pathology in cartilage tumors. Wolters Kluver, ( $3^{\text {rd }}$ edn), Philadelphia, 427-488.

20. White PG, Saunders L, Orr W (1996) Chondromyxoid fibroma. Skeletal Radiol 25: 79-81.

21. Gherlinzoni F, Rock R, Picci P (1983) Chondromyxoid fibroma. The experience at the instituto ortopedico Rizzoli. J Bone Joint Surg Am 65: 198-204.

22. Zilmer DA, Dorfman HD (1989) Chondromyxoid fibroma of bone: Thirtysix cases with clinicopathologic correlation. Human Pathol 20: 952. 